\title{
Pengaruh Psikoedukasi Keluarga Terhadap Ansietas Dan Depresi Keluarga Yang Mempunyai Anak Dengan Autis Di Sekolah Khusus Autis Harapan Utama Ananda Depok
}

\section{The Influence of Family Psychoeducation Program on the Anxiety and Depression Level of the Family with Autistic Childen in Harapan Utama Ananda School, Depok}

\author{
Ellya Qolina $^{1}$, Achir Yani S Hamid ${ }^{2}$ dan Ice Yulia Wardani ${ }^{3}$ \\ 1. Mahasiswa Magister Ilmu Keperawatan Peminatan Keperawatan Jiwa Fakultas Ilmu \\ Keperawatan Universitas Indonesia, Kampus FIK UI, Jl. Prof. Dr. Bahder Djohan, \\ Depok, Jawa Barat-16424 \\ Email: qolinaellya@gmail.com
}

2. Kelompok Keilmuan Keperawatan Jiwa Fakultas Ilmu Keperawatan Universitas Indonesia

\begin{abstract}
ABSTRAK
Mekanisme koping maladaptif sering terjadi pada orang tua yang mempunyai anak autis. Hal tersebut menyebabkan dampak psikologis seperti ansietas dan depresi pada keluarga terutama orang tua. Tujuan penelitian ini adalah untuk mengetahui pengaruh psikoedukasi keluarga terhadap ansietas dan depresi pada keluarga yang mempunyai anak autis. Desain penelitian yang digunakan adalah quasi eksperimen pre post test without control group. Sebanyak 21 orang tua yang mempunyai anak autis di Sekolah Khusus Autis Harapan Utama Depok diambil sebagai responden penelitian dengan metode total sampling. Variabel dianalisis dengan wilcoxon. Hasil penelitian menunjukkan bahwa psikoedukasi keluarga secara signifikan menurunkan ansietas dan depresi responden dengan nilai p 0,000 $(<0,05)$. Hasil penelitian ini merekomendasikan perawat jiwa komunitas untuk memberikan psikoedukasi keluarga pada keluarga yang mempunyai anak autis untuk meningkatkan koping adatif sehingga dapat secara mandiri mencegah atau menurunkan ansietas dan depresi.
\end{abstract}

Kata kunci : Psikoedukasi, keluarga dengan anak autis, ansietas, depresi

\section{PENDAHULIAN}

Penelitian dari Center for Diseases Control (CDC) di Amerika pada tahun 2008 menyatakan, bahwa perbandingan autisme pada anak usia 8 tahun yang terdiagnosa autisme adalah 1:80. Dalam sebuah penelitian Hongkong Study pada tahun 2008 melaporkan tingkat kejadian autisme di Asia prevalensinya mencapai 1.68 per 1000 untuk anak usia dibawah 15 tahun. Laki-laki lebih banyak daripada perempuan dengan perbandingan 4:1
(Handojo, 2003). Berdasarkan data BPS tahun 2010 diperkirakan terdapat lebih dari 112,000 anak Indonesia penyandang autisme pada rentang usia 5-19 tahun.

Menurut Sutadi (2011) autisme merupakan gangguan perkembangan neurobiologi yang berat terjadi pada anak sehingga menimbulkan masalah pada anak dalam berkomunikasi dan berhubungan dengan lingkungannya. Gejala anak dengan autisme menurut Yuwono (2009), pada kemampuan komunikasi dan bahasa akan 
terlihat lambat dalam bicara, membeo (echolalia) meracau dengan bahasa yang sulit dipahami, serta tidak mampu memahami pembicaraan orang lain. Penanganan autisme tidak hanya dilakukan pada masa masa kanak-kanak, namun membutuhkan penanganan jangka panjang (Adams, 2012), Dari tanda dan gejalanya tersebut, anak dengan autis merupakan anak yang mempunyai kebutuhan khusus dan memerlukan perhatian ekstra dari keluarga.

Keluarga merupakan sistem yang mempunyai anggota dan saling berinteraksi, interelasi untuk mencapai tujuan bersama (Mubarak dkk, 2009). Jika salah satu anggota keluarga mendapatkan gangguan, maka akan mempengaruhi dan mengganggu sistem dalam keluarga, sehingga berpengaruh pada lingkungan dan masyarakat (Friedman, 2011).

Reaksi pertama keluarga ketika menerima kenyataan bahwa anaknya didiagnosa autisme adalah rasa tidak percaya (shock), sedih, kecewa, merasa bersalah, marah dan bahkan menolak Tidak mudah bagi keluarga untuk melalui tahapan ini, sebelum pada akhirnya sampai pada tahap penerimaan (Koesoemo, Hamid, Wiarsih, 2009).

Menurut Gray (2003 dalam Koesoemo, 2009) bahwa 35 keluarga yang merawat anak dengan autis, lebih dari sepuluh tahun mengalami tekanan emosi yang terus menerus seperti depresi, kecemasan dan kemarahan. Kecemasan atau ansietas

merupakan perasaan khawatir yang berkaitan dengan perasaan tidak pasti dan tidak berdaya serta tidak adanya objek yang spesifik (Stuart, 2013).

Adapun tahapan yang dilalui dalam proses mencapai tahap penerimaan tahap denial (menolak menerima kenyataan), tahap anger (marah), tahap bargaining (menawar), tahap depression (depresi) dan tahap acceptance (pasrah dan menerima kenyataan) (Koesoemo, Hamid, Wiarsih, 2009). Depresi adalah bagian dari gangguan alam perasaan atau mood (Videback, 2008) yang mempengaruhi peran dan fungsi keluarga dalam merawat anak dengan autis dengan kebutuhan khusus yang harus dipenuhi keluarga.

Memiliki anggota keluarga berkebutuhan khusus menjadi beban psikologis dalam merawat anak dengan autis di samping beban finansial, emosional seperti perasaan malu atau perasaan bersalah apabila sudah berhadapan dengan fungsi sosial, sehingga keluarga menghindari situasi yang tidak menyenangkan (Sains, 2014). Selain kesulitan yang dirasakan, keluarga juga merasakan adanya pandangan negatif masyarakat dengan kondisi anak dengan autis, yang biasa disebut dengan stigma.

Stigma merupakan ciri negatif/label yang diberikan pada seseorang atau kelompok tertentu (Purwato, 2006) yang dirasakan oleh keluarga sehingga membuat keluarga cenderung melakukan isolasi sosial, psikis dan emosional serta menjadi beban rumah tangga dalam membesarkan anak (O'Brein, 2013). Para peneliti menegaskan bahwa ASD mengganggu kemampuan individu untuk memahami dalam proses berfikir dan akibatnya menghambat pembentukan hubungan Frih \& Happe (1999 dalam O’Brein 2013).

Di Indonesia, pendidikan khusus dilaksanakan melalui dua jalur, yaitu pada satuan pendidikan khusus (Sekolah Luar Biasa) dan pada sekolah regular (program pendidikan inklusi). Undang-Undang No. 20 tahun 2003 tentang Sistem Pendidikan Nasional pada pasal 32 ayat 1 memberikan jaminan bahwasanya anak-anak yang memiliki kebutuhan khusus memiliki hak mendapatkan pendidikan yang sama sebagaimana anak yang lain. Pernyataan dalam Undang-Undang no. 20 tahun 2003 tentang Sistem Pendidikan Nasional diperkuat dengan Peraturan Pemerintah no. 17 tahun 2010 tentang penyelenggaraan pendidikan dan Peraturan Menteri pendidikan Republik Indonesia no. 70 tahun 2009, tentang penyelenggaraan pendidikan untuk anak berkelainan dan anak cerdas istimewa dan bakat istimewa, 
yang memberikan arah secara operasional sebagaimana pendidikan inklusi.

Kurangnya sosialisasi tentang layanan pendidikan inklusi pada masyarakat berdampak pada harapan orang tua agar anak mereka sembuh setelah mendapatkan pendidikan dan memiliki kemampuan seperti anak-anak lainya. Untuk itu perlunya psikoedukasi keluarga pada keluarga yang mempunyai anak dengan autis, termasuk pada Sekolah Khusus Autis Harapan Utama Ananda Depok.

Sekolah Khusus Autis Harapan Utama Ananda Depok yang berada dibawah Yayasan Harapan Utama Ananda yang didirikan pada tanggal 9 Febuari 2012, beralamat di jalan Raden Saleh nomor 4, Kelurahan Sukmajaya, Depok. Sekolah Khusus Autis Harapan Utama Ananda Depok dipimpin oleh seorang kepala sekolah, dibantu oleh seorang wakil kepala sekolah dengan 18 orang guru dengan jumlah murid dengan autisme 36 murid.

Studi Pendahuluan dilakukan peneliti terhadap lima orang tua yang mempunyai anak dengan autis dan pihak sekolah yang diwakili oleh Penanggung Jawab Harian Yayasan. Dari hasil wawancara dengan lima orang tua murid diperoleh informasi bahwa pada awalnya mereka menolak, khawatir dan cemas terhadap kondisi anak mereka terkait dengan masalah komunikasi dan perilaku yang kadang-kadang sulit dikendalikan. Empat dari lima orang tua $(80 \%)$ mengatakan malu sehingga menyembunyikan kondisi anaknya yang didiagnosa autis dari lingkungan sekitarnya. Begitu juga dengan ungkapan penanggung jawab harian yayasan bahwa orang tua murid mempunyai kekhawatiran dan kecemasan terhadap anaknya namun mereka tidak mau mengakuinya.

Keluarga memerlukan dukungan internal (keluarga) dan eksternal (lingkungan) dalam melakukan perawatan anak dengan autis. Dukungan internal dan eksternal menjadi motivasi dan pemberdayaan keluarga untuk melakukan tindakan perawatan anak dengan autis (Koesoemo, Hamid, Wiarsih, 2009).
Berdasarkan latar belakang tersebut peneliti, merasa perlu melakukan sebuah penelitian untuk menghasilkan pengetahuan dasar yang akan berguna dalam mengembangkan suatu pendekatan kesehatan dan keperawatan jiwa dalam meningkatkan kemampuan keluarga dalam merawat anak dengan autis. Peneliti ingin meneliti tentang pengaruh psikoedukasi keluarga terhadap ansietas dan depresi pada keluarga yang mempunyai anak dengan autis di Sekolah Khusus Autis Harapan Utama Ananda Depok.

\section{BAHAN DAN METODE}

Desain penelitian ini adalah pre post test without control group dengan melakukan suatu perlakuan intervensi tanpa kelompok pembanding. Metode pengambilan sampel dengan teknik total sampling.

Penelitian ini dilakukan untuk mengetahui pengaruh psikoedukasi keluarga terhadap skor ansietas dan depresi keluarga yang mempunyai anak dengan autis. Pengukuran terdiri dari data demografi responden yang meliputi usia, jenis, kelamin, pendidkan, pekerjaan, penghasilan. Pengambilan data dengan menggunakan kuesioner A yang terdiri dari 5 pertanyaan dengan cara checklist dan mengisi pada kolom jawaban yang tersedia.

Pengukuran ansietas dan depresi keluarga dengan menggunakan kuesioner terkait ansietas terdiri dari 14 pernyataan dan kuesioner terkait depresi 14 pernytaan. Pernyataan pada kuesioner dalam bentuk skala likert. Instrumen diisi oleh responden langsung dan didampingi oleh peneliti. Jumlah pernyataan telah dilakukan uji validitas dan reliabilitas pada 20 responden yang memilki karakteristik yang sama dengan responden yang akan terlibat dalam penelitian. Kuesioner dengan penyataan ansietas dinyatakan valid dan reliabil dengan hasil $(0,533-0,877)>\mathrm{r}$ tabel $(0,444)$ dan memiliki nilai Alpha Cronbach 0,766. Pada kuesioner pada pernyataan depresi dinyatakan valid dan reliabil 
dengan hasil $(0,649-0,867)>\mathrm{r}$ tabel $(0,444)$.

Pelaksanaan psikoedukasi terdiri dari 5 sesi pelaksanaan dilakukan dalam kurun waktu setiap hari secara berselingan sesuai jadwal yang sudah disepakati dengan responden. Peneliti memberikan intervensi psikoedukasi pada keluarga yang mempunyai anak dengan autis yang terdiri dari lima sesi, dalam empat kali pertemuan, sesi pertama dan sesi dua dilakukan dalam satu kali pertemuan dengan lama pertemuan 45-60 menit dalam setiap kali pertemuannya. Pelaksanaan psikoedukasi keluarga dibagi dalam 4 kelompok, setiap kelompok berjumlah 5-6 pelaku rawat, Pelaksanaan psikoedukasi dilakukan terhadap 2 kelompok dalam 1 hari dengan waktu yang berbeda, jeda waktu antar 2 kelompok dengan 2 kelompok yang berbeda dalam pelaksanaan setiap pertemuan psikoedukasi keluarga adalah 2 hari, sehingga membutuhkan waktu 2 minggu untuk menyelesaikan 5 sesi psikoedukasi.

\section{HASIL PENELITIAN}

Karakteristik usia dan penghasilan respoden dalam penelitian ini dapat dilihat pada tabel 1

Tabel 1

Distribusi Responden Berdasarkan Usia dan

Penghasilan Keluarga di Sekolah Khusus Autis

Harapan Utama Ananda Depok Tahun 2015 $(\mathrm{N}=21)$

\begin{tabular}{|c|c|c|c|c|c|}
\hline No & Karakteristik & Median & SD & $\begin{array}{c}\text { Min- } \\
\text { maks }\end{array}$ & $95 \%$ CI \\
\hline 1 & Usia & 44 & 6.641 & $27-59$ & $40.98 ; 47.02$ \\
\hline 2 & Penghasilan & 7 & 6.722 & $1-30$ & $5.94 ; 12.05$ \\
\hline
\end{tabular}

Keterangan : Usia dalam tahun, Penghasilan dalam juta

Rata-rata usia responden, dari 21 responden adalah 44 tahun. Usia termuda 27 tahun dan usia tertua 59 tahun. Rata-rata penghasilan responden 7 juta. Hasil estimasi penghasilan dapat disimpulkan bahwa $95 \%$ rata-rata penghasilan responden antara 1 juta sampai dengan penghasilan terbesar 30 juta.

Tabel 2

Distribusi Responden Berdasarkan Jenis Kelamin, Pekerjaan, dan Pendidikan Terakhir di Sekolah Khusus Autis Harapan Utama Ananda Depok Tahun $2015(\mathrm{~N}=21)$

\begin{tabular}{|l|c|c|}
\hline \multicolumn{1}{|c|}{ Variabel } & Frekuensi & $\begin{array}{c}\text { Persentase } \\
(\%)\end{array}$ \\
\hline Jenis kelamin & 3 & 14.3 \\
Laki-laki & 18 & 85.7 \\
Perempuan & 8 & 38.1 \\
\hline Pekerjaan & 3 & 14.3 \\
Pegawai Swasta & 2 & 9.5 \\
Wiraswasta & 8 & 38.1 \\
Pegawai Negeri & & \\
Lain-lain & 8 & 38.1 \\
\hline $\begin{array}{l}\text { Pendidikan } \\
\text { terakhir } \\
\text { SMA/sederajat }\end{array}$ & 13 & 61.9 \\
Diploma/PT & & \\
\hline
\end{tabular}

Sebagaian besar adalah perempuan $85,7 \%$. Mayoritas pegawai swasta $38,1 \%$. Memilki tingkat pendidikan Diploma/PT $61,9 \%$.

Tabel 3

Analisis Skor Ansietas Sebelum dan Sesudah diberikan Psikoedukasi Di Sekolah Khusus Autis

Harapan Utama Ananda Depok Tahun 2015

\begin{tabular}{|l|c|c|c|c|c|c|}
\hline Variabel & $\mathrm{N}$ & $\begin{array}{c}\text { Median } \\
\text { Sebelum }\end{array}$ & $\begin{array}{c}\text { Median } \\
\text { sesudah }\end{array}$ & $\begin{array}{c}\text { Median } \\
\text { selisih }\end{array}$ & $\mathrm{Z}$ & $\begin{array}{c}\mathrm{P} \\
\text { value }\end{array}$ \\
\hline Ansietas & 21 & 15 & 9,00 & 6 & $-4,040$ & 0,000 \\
\hline
\end{tabular}

Hasil uji statistik pada tabel 5.4. menunjukkan bahwa nilai tengah (median) skor ansietas sebelum dilakukan psikoedukasi adalah 15 dengan kategori ansietas berat. Setelah diberikan terapi Psikoedukasi keluarga nilai tengah (median) ansietas menurun menjadi 9,00 dalam kategori ansietas ringan dengan selisih 6. Sehingga dapat disimpulkan bahwa terjadi perubahan yang bermakna dari penurunan skor ansietas keluarga dengan anak autis ( $\mathrm{p}$ value $<\alpha$ ). 
Tabel 4

Analisis Skor Depresi Responden Sebelum Dan

Sesudah Diberikan Psikoedukasi Di Sekolah

Khusus Autis Harapan Utama Ananda Depok Tahun $2015(\mathrm{~N}=21)$

\begin{tabular}{|c|c|c|c|c|c|c|}
\hline Variabel & N & $\begin{array}{c}\text { Median } \\
\text { Sebelum }\end{array}$ & $\begin{array}{c}\text { Median } \\
\text { sesudah }\end{array}$ & $\begin{array}{c}\text { Median } \\
\text { selisih }\end{array}$ & $\mathrm{Z}$ & P value \\
\hline Depresi & 21 & 12,00 & 10,00 & 2 & $-4,052$ & 0,000 \\
\hline
\end{tabular}

Hasil uji statistik pada tabel 5.6. menunjukkan bahwa nilai tengah (median) depresi sebelum dilakukan terapi Psikoedukasi keluarga adalah 12,00 kategori depresi ringan. Setelah diberikan terapi Psikoedukasi keluarga nilai tengah (median) depresi menurun menjadi 10,00 dalam kategori depresi ringan dengan selisih 2 ( $p$ value $<\alpha$ ).

Hal ini menunjukan bahwa ada hubungan kuat antara total skor depresi sebelum dan sesudah pemberian terapi psikoedukasi. Pemberian psikoedukasi dapat menurunkan skor depresi responden walaupun tingkat depresi responden sebelum dan sesudah pemberian psikoedukasi masih berada pada tingkat depresi ringan (jika dikategorikan).

Tabel 5.

Perbedaan ansietas dan depresi sebelum dan sesudah terapi psikoedukasi

\begin{tabular}{|c|c|c|c|c|}
\hline Variabel & $\begin{array}{c}\text { Median } \\
\text { sebelum }\end{array}$ & $\begin{array}{c}\text { Median } \\
\text { sesudah }\end{array}$ & $\begin{array}{c}\text { Median } \\
\text { selisih }\end{array}$ & $\begin{array}{c}P \\
\text { value }\end{array}$ \\
\hline Ansietas & 15 & 9,00 & 6 & 0,000 \\
\hline Depresi & 12 & 10 & 2 & 0,000 \\
\hline
\end{tabular}

Nilai median ansietas dan depresi responden sebelum dan sesudah mengalami perubahan secara bermakna $(p$ veleu $\leq \alpha)$ pada ansietas 15 menjadi 9 dengan selisih nilai median 6. Sedangkan skor depresi sebelum dan sesudah dilakukan psikoedukasi dengan skor 12 menjadi 10 dengan selisih nilai median $2(p$ veleu $\leq \alpha)$

\section{PEMBAHASAN}

Penelitian ini dilakukan untuk mengetahui pengaruh psikoedukasi terhadap ansietas dan depresi pada keluarga yang mempunyai anak dengan autis.
Ansietas mengalami penurunan skor 15 dalam kategori sedang menjadi skor 9 dalam kategori ringan. Sementara depresi mengalami penurunan, skor 12 dengan kategori ringan menjadi skor 10 dengan kategori ringan. Pemberian psikoedukasi dapat menurunkan skor depresi.

Proses pelaksanaan psikoedukasi keluarga pada penelitian ini memberikan kesempatan kepada responden untuk mengidentifikasi masalah-masalah yang berkaitan dalam merawat anak dengan autis yang memerlukan dukungan internal (keluarga maupun eksternal (lingkungan) sehingga keluarga dapat beradapasi dengan kondisi anggota keluarga berkebutuhan khusus, seperti yang diuraikan dalam teori model adaptasi Roy.

Intervensi psikoedukasi keluarga salah satu terapi keperawatan jiwa memberikan informasi, edukasi melalui komunikasi terapeutik (Stuart, 2009). Dalam pelaksanaanya membantu keluarga mengidentifikasi dan memperbaiki keadaan yang mal adaptif, kontrol diri yang kurang bertujuan memobilisasi kekuatan dan sumber fungsi, merestrukturisasi gaya perilaku keluarga yang maladaptif dan menguatkan perilaku penyelesaian masalah keluarga Strenglass (1995 dalam Videback, 2008)

Hasil penelitian tingkat ansietas keluarga dengan anak autis sebelum dan sesudah pemberian terapi psikoedukasi. menunjukan dapat menurunkan tingkat ansietas secara bermakna pada keluarga yang mempunyai anak dengan autis dari rata-rata 15 dengan kategori ansietas sedang menjadi 9 dengan kategori ansietas ringan. Peneliti berpendapat bahwa kondisi anak dengan autis berdampak terhadap kondisi kecemasan keluarga keluarga seperti dilaporkan Hines et al. (2012) dan mampu meningkatkan kemampuan keluarga dalam mengatasi ansietas, bahwa orang tua/pengasuh melaporkan adanya stress dan kecemasan terkait dengan merawat anak dengan Autis

Memiliki anggota keluarga yang berkebutuhan khusus menjadi beban 
psikologis dalam merawat mereka di samping beban finansial, emosional seperti perasaan malu atau perasaan bersalah apabila sudah berhadapan dengan fungsi sosial, sehingga keluarga menghindari situasi yang tidak menyenangkan (Sains, 2014). Dalam kondisi tersebut keluarga memerlukan dukungan internal (keluarga) dan eksternal (lingkungan) dalam melakukan perawatan anak dengan autis. untuk mengembangkan potensi setiap anggota keluarga dalam menjalankan peran dan fungsi masing-masing, sehingga dapat memberikan pelayanan kesehatan kepada anggota keluarga yang lain (Hamid dkk, 2010).

Peran perawat jiwa sangat penting dalam memberikan tindakan keperawatan diantaranya adalah terapi psikoedukasi keluarga, sesuai dengan tujuan terapi psikoedukasi keluarga dapat meningkatkan pengetahuan tentang autis, menejemen stress, menejemen beban dan pemberdayaan komunitas dalam membantu keluarga, dalam merawat anak dengan autis, dalam setiap sesinya disertai diskusi yang dilakukan kelompok. sehingga dapat bertukar pengalaman dalam merawat anak dengan autis.

Kondisi depresi pada keluarga/pelaku rawat lebih berkaitan dengan pikiran negatif dan pengalaman mereka diinterpretasikan sebagai hal yang sulit dan membebani, sehingga mereka memandang diri sendiri, dunia, dan masa depan dalam bentuk kegagalan, Aaron Beck (1976 dalam Videbeck, 2010). Perasaan sensitif, perasa, mudah tersinggung, lebih suka sendiri. Kondisi ini dikuatkan dengan perasaan bersalah dari keluarga terhadap kondisi anak dengan autis dan masih adanya stigma dari lingkungan sekitarnya terhadap keluarga, sehingga keluarga merasakan kurangnya dukungan baik dari keluarga dekat maupun lingkungan sekitarnya.

Menurut Kubler-Ross (1969 dalam Perry \& Potter 2005), tahapan proses kehilangan yaitu tahapan menolak, marah, tawar menawar, depresi sampai pada tahap menerima, dimana keluarga yang mempunyai anak dengan autis mengalami kehilangan perubahan perkembangan. Kondisi keluarga dengan anak autis, anak mengalami hambatan dalam komunikasi, interaksi dan sosialisasi (Sutadi, 2011)

Menurut Hanson (1996 dalam Hamid dkk, 2010) bahwa keluarga yang secara konsisten terpapar stres akan membangun strategi koping untuk mempertahankan keseimbangan. Sejalan dengan teori Calista Roy (1991). Bahwa manusia sebagai individu, keluarga, kelompok dan masyarakat merupakan sebuah sistem dan dapat menyesuaikan diri (adaptif system). Seperti yang sudah diuraikan pada pembahasan ansietas pada kondisi depresi dalam beradaptasi manusia menggunakan empat model yaitu fungsi fisiologis, fungsi peran, konsep diri dan interdependensi, dengan menggunakan sistem adaptasi, yaitu sistem regulator dan kognator.

Hasil penelitian pemberian terapi psikoedukasi keluarga pada keluarga yang mempunyai anak dengan autis menunjukkan bahwa nilai tengah (median) tingkat depresi sebelum dilakukan psikoedukasi adalah 12 kategori depresi ringan, setelah diberikan psikoedukasi keluarga tingkat ansietas menurun menjadi 10 dalam kategori depresi ringan dengan selisih $2(p$ value $<\alpha)$. Hal ini menunjukan adanya hubungan kuat antara total skor depresi responden sebelum dan sesudah pemberian psikoedukasi keluarga dapat menurunkan skor depresi responden, walaupun tetap berada pada tingkat depresi ringan (jika dikategorikan).

Hasil penelitian tersebut peneliti berpendapat perlunya terapi lain yang dapat digabungkan untuk membantu keluarga dalam hal ini pelaku rawat mengatasi kondisi depresi. Menurut Videbeck (2008) psikoterapi dapat diberikan baik kepada individu, keluarga maupun kelompok. Dimana terapi yang diberikan kepada individu bertujuan untuk menimbulkan perubahan pada individu dengan cara mengkaji perasaan, sikap, cara berpikir dan cara individu berperilaku. Menurut Rupke, 
Blecke dan Renfrow ( 2006 dalam program Studi Ners spesialis Keperawatan Jiwa FIK UI, 2014) terapi kognitif efektif untuk mengatasi emosi negatif seperti ansietas dan depresi yang disebabkan oleh interpretasi yang keliru terhadap peristiwaperistiwa yang mengganggu serta dapat meningkatkan harga diri. Terapi kognitif merupakan bentuk psikoterapi yang didasarkan pada konsep proses patologi jiwa, fokus tindakannya berdasarkan modifikasi dari distorsi kognitif dan perilaku maladaptif (Townsend, 2009). Menurut Townsend (2009) tujuan terapi kognitif sebagai monitor pikiran otomatis negatif, mengetahui hubungan antara pikiran, perasaan dan perilaku, mengubah penalaran yang salah menjadi penalaran yang logis, dan membantu pasien mengidentifikasi dan mengubah kepercayaan yang salah sebagai pengalaman negatif internal pasien. Pemberian terapi kognitif diharapkan dapat merubah pikiran otomatis negatif klien menjadi pikiran positif.

\section{KESIMPULAN}

a. Karakteristik dari 21 responden ratarata usia adalah 44. Tahun, sebagian besar responden adalah perempuan, mayoritas pekerjaan responden adalah pegawai swasta, latar belakang pendidikan responden terbanyak berpendidikan PT/Diploma, rata-rata penghasilan responden antara 1 juta sampai dengan penghasilan terbesar 30 juta

b. Gambaran ansietas dan depresi keluarga yang mempunyai anak dengan autis seelum dilakukan psikoedukasi keluarga berada pada ansietas berat dan depresi ringan.

c. Terapi psikoedukasi keluarga dapat menurunkan tingkat ansietas secara bermakna dari ansietas berat dengan skor 15 menjadi ansietas ringan dengan skor 9, dengan selisih skor 6

d. Terapi psikoedukasi keluarga dapat menurunkan skor depresi dengan skor 12 menjadi skor 10 dengan selisih skor
2 walaupun masih berada dalam kategori depresi ringan.

\section{SARAN}

a. Hasil penelitian dapat digunakan sebagai salah satu acuan pengembangan aplikasi intervensi lanjutan guna meningkatkan mutu pelayanan keperawatan jiwa oleh perawat spesialis keperawatan jiwa khususnya terapi psikoedukasi keluarga yang dapat digabungkan dengan terapi spesialis lainya seperti terapi kognitif atau terapi perilaku khususnya dalam menurunkan skor depresi pada keluarga yang mempunyai anak dengan autis

b. Hasil penelitian dapat digunakan sebagai data dasar pengembangan intervensi terapi spesialis tidak hanya satu terapi dalam intervensi khususnya intervensi yang diberikan oleh perawat spesialis keperawatan jiwa dalam bidang keperawatan jiwa

c. Penelitian ini dapat dilanjutkan dengan menambahkan kelompok kontrol sebagai pembanding sehingga hasilnya dapat diketahui perbedaan pemberian psikoedukasi pada kelompok yang mendapatkan psikoedukasi dan yang tidak mendapatkan terapi psikoedukasi.

\section{DAFTAR PUSTAKA}

\section{Family Life with Children with Autism Spectrum Disorders \\ (http://life.familyeducation.com/autis m/family/59199.html). Diunduh pada 26 Februari 2015, pukul 00:26 WIB.}

Friedman, Marilyn M. (2003). Family Nursing: Research, Theory, and Practice Fifth Edition. New Jersey: Pearson Education, Inc.

Friedman, Marilyn M. (2010). Buku Ajar Keperawatan Keluarga: Riset, Teori, dan Praktik Ed. 5. Jakarta: EGC (Alih Bahasa Hamid, Achir Yani, dkk). 
Fontaine Kareen Lee. (2009). Mental Health Nursing, $7^{\text {th }}$ ed, New Jersy: Pearson Education, Inc.

Handoyo. (2009). Autisme Pada Anak. Jakarta: Bineka Ilmu Popular

O'Brien, Sandra L. (2013). The Influence of Daily Stressors, Severity of Behavior Problems, Uncertainty, and Coping Strategies on Family Adaptation in Families of Adolescents with Autism Spectrum Disorders. Washington, D.C.

Potter, P.A \& Perry, A.G. (2005). Buku Ajar Fundamental Keperawatan: Konsep, Proses, dan Praktik. Alih Bahasa: Yasmin Asih. Jakarta: EGC.

Sabri, L. \& Hastono, S.P. (2014). Statistik Kesehatan Edisi Kedua. Jakarta: PT Raja Grafindo Persada.
Sastroasmoro, S. \& Ismael, S. (2008). Dasar-Dasar Metodologi Penelitian Klinis Edisi 3. Jakarta: Sagung Seto.

Stuart, G.W. (2013). Principles and Practice of Psychiatric Nursing $\left(9^{\text {th }}\right.$ edition). St Louis. Canada: Mosby.Inc.

Shimodera, et al. (2012). Cost-effectiveness of Family Psychoeducation To Prevent Relapse In Major Depression: Result From A Randomized Controlled Trial. BioMed Central Ltd.

Tomey- Alligood. (2010). Nursing Theory; Utilization and Application, Mosby

Videbeck, S.L. (2011). Pychiatric Mental Health Nursing. ( ${ }^{\text {rd }}$ edition). Philadhelpia: Lippincott Williams \& Wilkin. 